\title{
CELLULOSE DIGESTION IN Monochamus marmorator Kby. (COLEOPTERA: CERAMBYCIDAE): Role of Acquired Fungal Enzymes
}

\author{
JEROME J. KUKOR and MICHAEL M. MARTIN \\ Division of Biological Science \\ University of Michigan \\ Ann Arbor, Michigan 48109-1048
}

(Received June 26, 1985; accepted August 13, 1985)

\begin{abstract}
Larvae of the balsam fir sawyer, Monochamus marmorator Kby. (Coleoptera, Cerambycidae), contain midgut digestive enzymes active against hemicellulose and cellulose. Cellulases from larvae fed on balsam fir wood infected with the fungus, Trichoderma harzianum Rifai (Deuteromycetes, Moniliales, Moniliaceae), were found to be identical to those of the cellulase complex produced by this fungus when compared using chromatography, electrophoresis, and isofocusing. When larvae are maintained on a fungusfree diet, their midgut fluids lack cellulolytic activity, and they are unable to digest cellulose. Cellulolytic capacity can be restored by feeding the larvae wood permeated by fungi. We conclude that the enzymes which enable $M$. marmorator larvae to digest cellulose are not produced by the larvae. Instead, the larvae acquire the capacity to digest cellulose by ingesting active fungal cellulases while feeding in fungus-infected wood.
\end{abstract}

Key Words-Cellulases, xylophagy, cellulolysis, acquired enzymes, nutritional ecology, Monochamus marmorator, Trichoderma harzianum, Coleoptera, Cerambycidae, Moniliaceae.

\section{INTRODUCTION}

The ability of wood-boring larvae of cerambycid beetles to utilize the structural polysaccharides in their food has been the subject of many investigations dating back to the early 1900s (Linsley, 1959). Cellulolytic enzymes have been detected in the gut fluids of many species (Dajoz, 1968; Chararas et al., 1971; Chararas, 1981), and approximate digestibility measurements have demonstrated that between 12 and $57 \%$ of ingested cellulose may be assimilated (Martin, 1983). At one time it was believed that intracellular symbionts might play 
a role in cellulose digestion in these beetles (Buchner, 1928; Campbell, 1929; Uvarov, 1929), but this possibility has failed to receive confirmation (Mansour and Mansour-Bek, 1934a, b; Parkin, 1940). The inability to demonstrate symbiont-mediated cellulolysis has led to the assumption that cerambycid larvae produce all of the enzymes necessary for cellulose digestion, although there is little evidence to support this assumption.

Cellulose digestion is generally accomplished by a collection of enzymes (the cellulase complex) consisting of three major classes of hydrolases: endoglucanases $\left(C_{x}\right.$-cellulases), cellobiohydrolases $\left(C_{1}\right.$-cellulases), and $\beta$-glucosidases (e.g., cellobiases) (Martin, 1983). In no study of any species of cerambycid beetle has compelling evidence been presented that all of the requisite enzymes of the cellulase complex are produced by the larvae themselves.

We have studied cellulose digestion in the balsam fir sawyer, Monochamus marmorator Kby. (Cerambycidae, Lamiinae). Larvae of this species tunnel extensively through the wood of moribund balsam fir (Abies balsamea) stems, frequently passing through patches of wood decayed by white rot fungi. The objective of this study was to determine whether the capacity of M. marmorator larvae to digest cellulose is due to fungal enzymes ingested by the larvae during feeding. Our research on $M$. marmorator is part of ongoing investigations into the roles of acquired fungal enzymes in the digestive processes and nutritional ecology of xylophagous insects (Martin, 1984).

\section{METHODS AND MATERIALS}

Collection and Maintenance of Larvae. M. marmorator larvae were collected from moribund stems of balsam fir at the University of Michigan Biological Station, Cheboygan County, Michigan. Larvae were maintained in the laboratory at $22^{\circ} \mathrm{C}$ in 150 -ml wide-mouth polyethylene jars containing decayed balsam fir wood chips (BFWC), kept at a 30-50\% moisture content. In experiments that involved larvae reared on a fungus-free medium, $40 \mathrm{M}$. marmorator larvae were reared for two to four weeks in $25-\mathrm{ml}$ plastic cups containing small blocks of a wheat germ-casein artificial diet (Tobacco Hornworm Diet, BioServ). Larvae have been successfully maintained on this diet for over nine months.

Isolation and Maintenance of Fungi. Fungi associated with the galleries of M. marmorator larvae in balsam fir stems were isolated by placing small wood chips, removed aseptically from the wood adjacent to larval galleries, onto plates of $1.5 \%$ malt extract agar, $4 \%$ potato dextrose agar, and $5 \%$ Czapek agar (Difco).

For the production and harvest of cellulase, Trichoderma harzianum was grown in 7-liter batches on a medium of the following composition (ingredients given in grams per liter): microcrystalline cellulose (Polysciences), 5.0; $\left(\mathrm{NH}_{4}\right)_{2} \mathrm{SO}_{4}, 2.0 ; \mathrm{KH}_{2} \mathrm{PO}_{4}, 1.7 ; \mathrm{K}_{2} \mathrm{HPO}_{4} \cdot 3 \mathrm{H}_{2} \mathrm{O}, 0.5 ; \mathrm{MgSO}_{4} \cdot 7 \mathrm{H}_{2} \mathrm{O}, 0.5$; 
$\mathrm{CaCl}_{2} \cdot 2 \mathrm{H}_{2} \mathrm{O}, 0.05 ; \mathrm{H}_{3} \mathrm{BO}_{3}, 2 \times 10^{-4} ; \mathrm{CuSO}_{4} \cdot 5 \mathrm{H}_{2} \mathrm{O}, 3 \times 10^{-4} ; \mathrm{ZnSO}_{4} \cdot$ $7 \mathrm{H}_{2} \mathrm{O}, 4 \times 10^{-3} ; \mathrm{MnCl}_{2} \cdot 4 \mathrm{H}_{2} \mathrm{O}, 1 \times 10^{-3} ; \mathrm{FeSO}_{4} \cdot 7 \mathrm{H}_{2} \mathrm{O}, 1 \times 10^{-3} ; \mathrm{CoCl}_{2}$ - $6 \mathrm{H}_{2} \mathrm{O}, 3 \times 10^{-4} ;\left(\mathrm{NH}_{4}\right)_{6} \mathrm{Mo}_{7} \mathrm{O}_{24} \cdot 4 \mathrm{H}_{2} \mathrm{O}, 2 \times 10^{-4}$. Incubation was on $\mathrm{a}$ rotary shaker at $22^{\circ} \mathrm{C}$ for two weeks.

Extract Preparation and Enzyme Assays. Midguts were dissected from $M$. marmorator larvae as described by Martin et al. (1980). Since the $\mathrm{pH}$ of the midgut fluid ranged between 6.2 and 6.9 , extracts were prepared in $50 \mathrm{~m} M$ Bis-Tris- $\mathrm{HCl}$ buffer [bis(2-hydroxyethyl)imino-tris(hydroxymethyl)methane] (Sigma), pH 6.5. For enzyme assays, the pooled midguts from one to three larvae were prepared as described in Martin et al. (1981). For purification of the cellulase enzyme complex from $M$. marmorator gut fluid, the midguts from 30 larvae were pooled.

Total activity of the cellulase complex was determined by incubating 0.5 $\mathrm{ml}$ of suitably diluted extract with $0.5 \mathrm{ml}$ of $0.5 \%$ microcrystalline cellulose suspended in $0.1 \mathrm{M}$ sodium acetate buffer, $\mathrm{pH} 5.0$, at $45^{\circ} \mathrm{C}$ for $2 \mathrm{hr}$. Carboxymethylcellulase and xylanase activity were determined with $0.5 \%$ carboxymethylcellulose, sodium salt (Sigma), or $0.5 \%$ larchwood xylan (United States Biochemical), in sodium acetate buffer, with incubation at $45^{\circ} \mathrm{C}$ for $1 \mathrm{hr}$. The incubation was terminated by the addition of $1.0 \mathrm{ml}$ of alkaline dinitrosalicylic acid (DNSA) reagent (Bernfeld, 1955). Insoluble cellulose and xylan were removed by centrifugation at $3500 \mathrm{~g}$ for $1 \mathrm{~min}$. The supernatant solution was then heated at $110^{\circ} \mathrm{C}$ for $8 \mathrm{~min}$, diluted with $1.5 \mathrm{ml}$ of water, and the absorbance at $540 \mathrm{~nm}$ determined. Enzyme/reagent blanks were prepared using heat-denatured aliquots of extract.

Cellulase Purification and Analysis. The cellulase enzyme complex from T. harzianum was purified from 28 liters of two-week-old culture fluid as previously described (Kukor and Martin, 1983). The cellulase complex from $M$. marmorator larvae reared on T. harzianum-infected BFWC was prepared from the pooled midguts of 30 larvae, and the cellulase from artificial diet-reared larvae was prepared from the pooled midguts of 12 animals.

$M$. marmorator cellulase purification was achieved by an initial ammonium sulfate fractionation, with all of the cellulase activity contained in the 26$50 \% \mathrm{~S}$ ammonium sulfate fraction. Precipitated proteins were collected by cen-

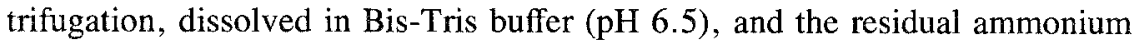
sulfate was removed by diafiltration in a stirred cell. Total protein was estimated by the dye-binding method of Bradford (1976).

The Trichoderma and Monochamus enzyme preparations were fractionated by high-resolution anion-exchange chromatography using a fast protein liquid chromatography (FPLC) system (Pharmacia). FPLC separations were carried out at a flow rate of $1.0 \mathrm{ml} / \mathrm{min}$ with an HR5/5 MonoQ column equilibrated with $50 \mathrm{mM}$ Bis-Tris buffer ( $\mathrm{pH} \mathrm{6.5)} \mathrm{containing} 10 \mathrm{mM} \mathrm{KCl}$. Proteins were eluted with a $10-500 \mathrm{mM}$ linear $\mathrm{KCl}$ gradient, and $1.0-\mathrm{ml}$ fractions were collected. 
Discontinuous-SDS-gradient gel electrophoresis was performed on 7.5$15 \%$ polyacrylamide gels using the system of Neville, as modified by Piccioni et al. (1982). Gels were stained with brilliant blue R250 (Sigma). Analytical isoelectric focusing was performed on ultrathin polyacrylamide gels (Servalyt Precotes, Serva Fine Biochemicals), as previously described (Kukor and Martin, 1983).

$\left[{ }^{14} \mathrm{C}\right]$ Cellulose Utilization. For $\left[{ }^{14} \mathrm{C}\right]$ cellulose utilization experiments, individual larvae were placed in stoppered $25-\mathrm{ml}$ scintillation vials. The bottom of each vial was coated with a thin layer of $2 \%$ agar in $0.1 \mathrm{~N} \mathrm{HCl}$, which provided moisture for the larva while it was feeding on the labeled cellulose. The headspace in each vial was periodically flushed with air at a flow rate of $30 \mathrm{ml} / \mathrm{min}$ for $15 \mathrm{~min}$, and the ${ }^{14} \mathrm{CO}_{2}$ in the exit gas was bubbled through phenethylamine $(1: 1 \mathrm{v} / \mathrm{v}$ in $\mathrm{MeOH})$ in ACS counting scintillant (Amersham). The trapping efficiency of this system was $90 \%$.

Each animal was provided with a $100-\mathrm{mg}$ food tablet made from $\alpha$-cellulose fiber (Sigma) amended with $5 \%(\mathrm{w} / \mathrm{w})\left[\mathrm{U}-{ }^{14} \mathrm{C}\right]$ cellulose (ICN). The labeled cellulose was repurified before use according to the procedure of Rapson (1963), to ensure removal of any water- or alkali-soluble noncellulosic contaminants that might have been present. The specific activity of labeled cellulose in each food tablet was calculated from the amount of radioactivity in weighed portions of the tablets, which were digested in $67 \%$ sulfuric acid and diluted 10 -fold with water before mixing with counting scintillant.

Counting efficiency was estimated by the $\mathrm{H}$-number method or by internal standards, as appropriate.

Assimilation Efficiencies. For approximate digestibility determinations, larvae from two groups (those reared for four weeks on $T$. harzianum-infected BFWC and those reared for two weeks on artificial diet followed by two weeks on autoclaved BFWC) were placed in individual $150-\mathrm{ml}$ polyethylene bottles containing 4-5 g (wet weight) of autoclaved BFWC. The jars, covered with Saran wrap, were incubated at $22^{\circ} \mathrm{C}$, and the diet was kept at $30-50 \%$ moisture content by periodic addition of sterile distilled water. After seven days, uneaten food and fecal pellets were separated using a series of standard mesh sieves. Food fragments were retained on a $1-\mathrm{mm}$ mesh screen, whereas the fecal pellets were collected on 0.5 - and $0.4-\mathrm{mm}$ mesh screens. The few small food fragments that passed onto the $0.5-\mathrm{mm}$ and $0.4-\mathrm{mm}$ mesh screens could be separated from the spherical fecal pellets by allowing the pellets to roll down an inclined metal pan subjected to moderate vibration by tapping with a pencil. Approximate digestibility was determined on a dry weight basis as $A D(\%)=100$ (food ingested - feces)/food ingested.

The cellulose content of BFWC and M. marmorator fecal pellets was estimated by the procedure of Updegraff (1969). 
Digestive Enzymes of M. marmorator. The digestive fluids from the midguts of $M$. marmorator larvae, either collected from their natural galleries in balsam fir stems or cultured in the laboratory on balsam fir wood chips permeated by mycelium of the fungus, $T$. harzianum, contain enzymes that enable them to digest both cellulose and hemicellulose (Table 1). Activity toward microcrystalline cellulose indicates the presence of the entire cellulase complex required to degrade native cellulose, while activity toward carboxymethylcellulose (CMC) indicates the presence of endoglucanases ( $\mathrm{C}_{x}$-cellulases) which attack soluble degradation products of cellulose or amorphous regions of the predominantly crystalline structure of native cellulose. Activity toward larchwood xylan indicates the presence of enzymes required to degrade arabino-4$\mathrm{O}$-methylglucuronoxylans, which are a major class of hemicelluloses present in both hardwoods and softwoods. Although the assays were routinely conducted at a $\mathrm{pH}$ of 5.5, the cellulolytic and hemicellulolytic enzymes exhibit significant activity in the $\mathrm{pH}$ range $6.2-6.9$ observed in the midgut fluids of these beetle larvae. Since cellulose and arabino-4-O-methylglucuronoxylans make up 42 and $9 \%$, respectively, of the dry weight of extractive-free balsam fir wood (Côté, 1977), the presence of cellulases and xylanases in the gut fluid of M. marmorator larvae is of obvious adaptive value.

In contrast to larvae from natural galleries or reared on fungus-infected wood, larvae fed for two weeks on a fungus-free artificial diet have gut fluid in which activity toward microcrystalline cellulose is barely detectable (Table 1). CMCase and xylanase activity is still evident, albeit at somewhat reduced levels, in the larvae from the fungus-free diet. When cellulase-free larvae are transferred from the artificial diet to autoclaved fungus-infected balsam fir wood chips, they do not regain the enzymes of the cellulase complex. This finding demonstrates that the cellulolytic activity of the gut fluid of larvae reared on normal fungus-infected wood is not due to enzymes of insect origin, the secretion of which is induced by heat-stable components of the normal diet, but instead suggests that cellulolytic activity might be due to ingested fungal enzymes. CMCase and xylanase activity is increased in larvae transferred to autoclaved, fungus-infected wood.

Fungi Associated with M. marmorator Galleries. The galleries of middleto late-instar M. marmorator larvae often pass through regions of wood decayed by white rot fungi. Although we have not conducted an exhaustive study to characterize all of the fungi associated with $M$. marmorator galleries, we did establish that Hirschioporus abietinus, Stereum sanguinolentum, Amylostereum chailletii, and Trichoderma harzianum are readily isolated from the wood adjacent to larval galleries. $T$. harzianum was the species most frequently isolated. 


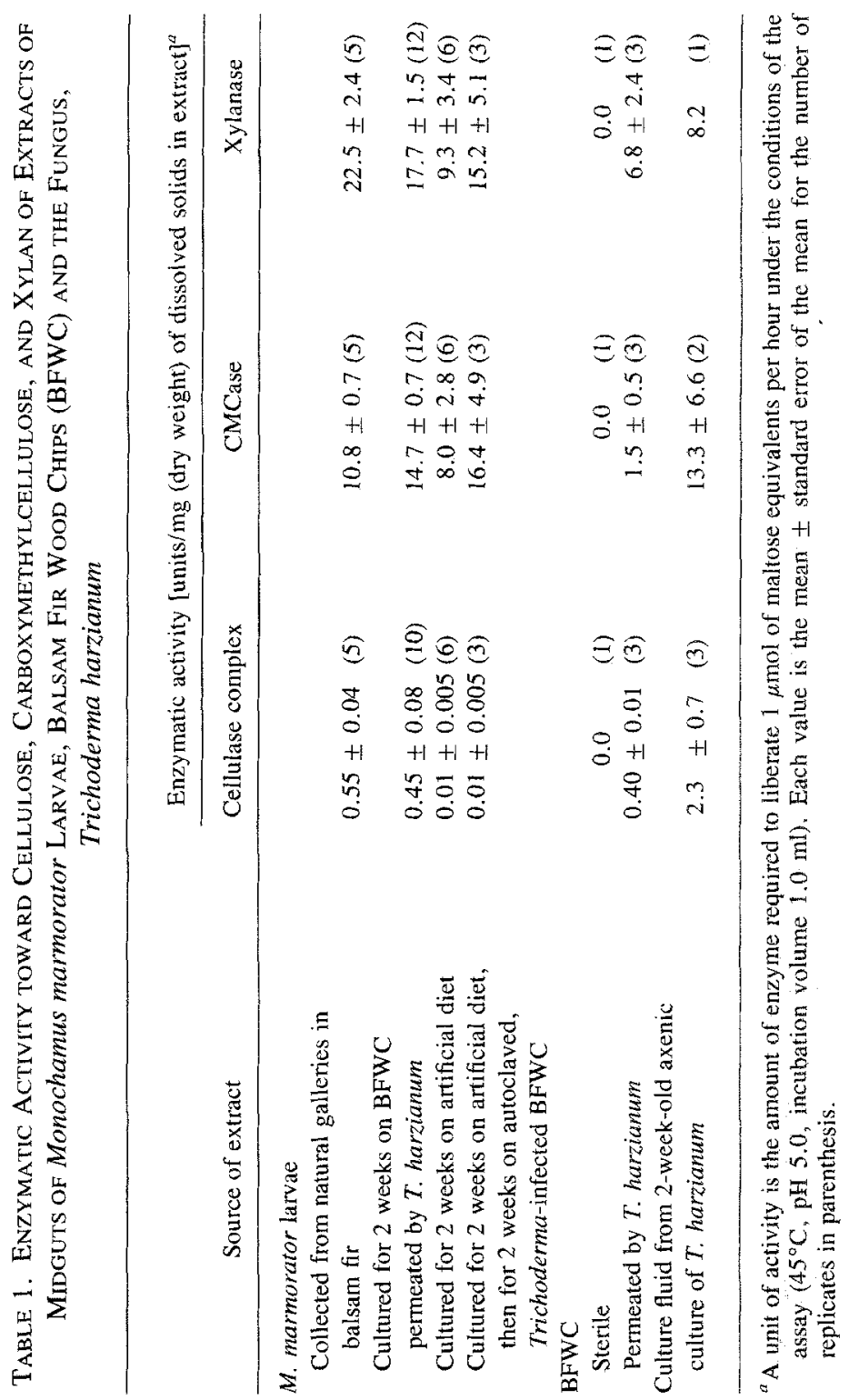


All of these fungi are cellulose digesters and hence are potential sources of cellulolytic enzymes. In agreement with the hypothesis that the beetle larvae are acquiring a capacity to digest cellulose through the ingestion of fungal cellulases, we demonstrated activity toward microcrystalline cellulose, carboxymethylcellulose, and larchwood xylan in an extract of balsam fir wood permeated by the mycelium of $T$. harzianum, as well as in the culture fluid of $T$. harzianum grown on microcrystalline cellulose in a defined medium (Table 1).

Purification and Comparison of Monochamus and Trichoderma Cellulases. When subjected to high-resolution anion-exchange chromatography (FPLC), $84 \%$ of the total activity toward microcrystalline cellulose in the gut fluid of larvae fed T. harzianum-infected wood eluted at $0.15 \mathrm{M} \mathrm{KCl}$ in a single large protein peak (Figure 1A). This peak was absent in the gut fluid of larvae cultured sequentially on an artificial diet and then on autoclaved T. harzianuminfected balsam fir wood chips (Figure 1B), although there was some activity toward carboxymethylcellulose and xylan associated with the various protein peaks in the elution profile. When the culture fluid from $T$. harzianum was subjected to a similar separation, a large protein peak eluted at $0.15 \mathrm{M} \mathrm{KCl}$ which accounted for $67 \%$ of the total activity toward microcrystalline cellulose (Figure 1C).

A comparison of the major cellulase peak from the insect and fungal preparations was made by discontinuous, denaturing-gel electrophoresis and isoelectric focusing. On an SDS-gradient gel, the FPLC cellulase fractions from $T$. harzianum culture fluid and from the gut extract of $M$. marmorator reared on $T$. harzianum-infected balsam fir wood chips show identical patterns of protein

A

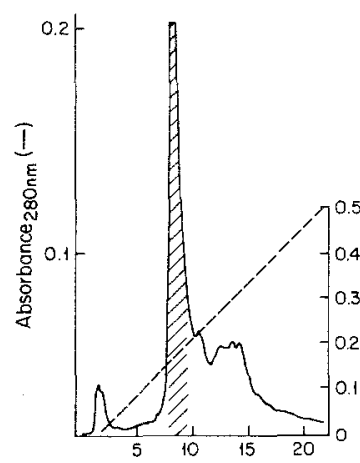

B

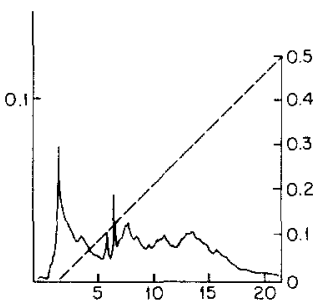

C

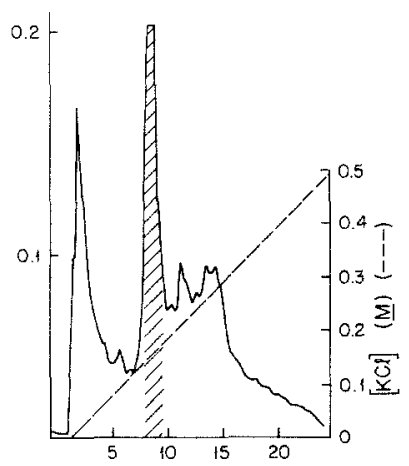

FIG. 1. FPLC elution profiles of $M$. marmorator midgut extracts and $T$, harzianum culture fluid. (A) $M$. marmorator reared on $T$. harzianum-infected BFWC. (B) $M$. marmorator reared on artificial diet and then on autoclaved $T$. harzianum-infected BFWC. (C) Fluid from an axenic culture of $T$. harzianum grown on a defined medium. Crosshatching indicates fractions with most of the activity against microcrystalline cellulose. 


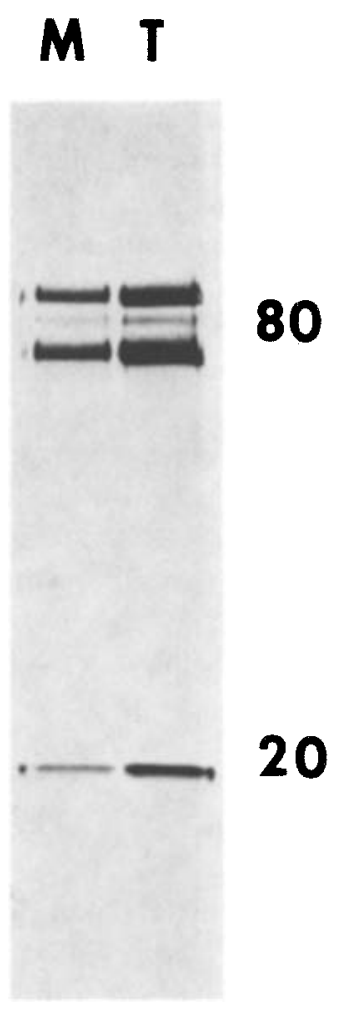

FIG. 2. SDS-gradient gel (7.5-15\%) of the major FPLC cellulase peaks from $M$. marmorator reared on T. harzianum-infected BFWC (M), and culture fluid of T. harzianum grown on a defined medium (T). Apparent molecular masses of the major bands: 83.9, $80.0,70.0$, and $17.9 \mathrm{kD}$.

bands (Figure 2). The four major bands have apparent molecular masses of $83.9,80.0,70.0$, and 17.9 kilodaltons. In an analytical isoelectric focusing gel (Figure 3), the fungal and insect FPLC cellulase fractions also have identical patterns, appearing as a broad band focused between $\mathrm{pH} 4.73$ and 5.07, with the highest density of protein at $\mathrm{pH}$ 5.0. These comparisons of fungal and insect cellulases demonstrate that the enzymes responsible for activity toward microcrystalline cellulose in the digestive fluids of $M$. marmorator larvae reared on T. harzianum-infected wood are identical to the enzymes produced by this same fungus grown in a defined medium, and they confirm our hypothesis that the insects acquire essential digestive enzymes by the ingestion of fungi or fungal enzymes present in wood they consume.

$\left[{ }^{14} \mathrm{C}\right]$ Cellulose Utilization. In order to demonstrate the importance of ingested fungal enzymes to cellulose digestion, we fed larvae $\left[\mathrm{U}^{1}{ }^{14} \mathrm{C}\right]$ cellulose 


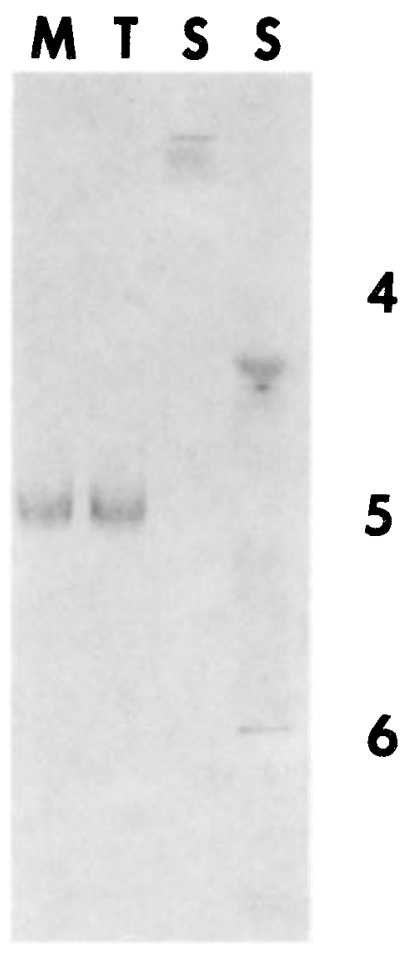

FIG. 3. Analytical isoelectric focusing on an ultrathin polyacrylamide gel (Serva Precote, nominal $\mathrm{pH}$ range 4-6) of the major FPLC cellulase peaks from $M$. marmorator reared on $T$. harzianum-infected BFWC (M), culture fluid of $T$. harzianum grown on a defined medium (T), and isoelectric point marker proteins (S). The marker proteins used and their corresponding $\mathrm{pI}$ values are pepsinogen, 2.80; amyloglucosidase, 3.50; glucose oxidase, 4.15 ; $\beta$-lactoglobulin, 5.34 ; conalbumin, 5.9.

and determined the percentage of ${ }^{14} \mathrm{C}$ from the food incorporated into respired carbon dioxide and body tissue (Table 2). The production of significant amounts of ${ }^{14} \mathrm{C}$-labeled carbon dioxide by larvae reared on a fungus-containing diet (larvae $1,2,3$ ) and the incorporation of ${ }^{14} \mathrm{C}$ into the fat body and integument (larva 1) clearly reveal the ability of these insects to digest cellulose, while the absence of any labeled carbon dioxide in the respiratory gases from larvae reared on a fungus-free diet (larvae $4,5,6,7$ ) shows that they are unable to digest cellulose. In this set of experiments it was also demonstrated that a larva that had lost its acquired cellulases by maintenance on a fungus-free diet for two weeks (larva 5) regained cellulolytic capacity after only $24 \mathrm{hr}$ on a diet of fungus-infected wood. A second larva (larva 6) did not regain its cellulolytic capacity after feeding for $24 \mathrm{hr}$ on fungus-infected wood that had been autoclaved in order to kill the fungus and deactivate any fungal enzymes that had been secreted into 


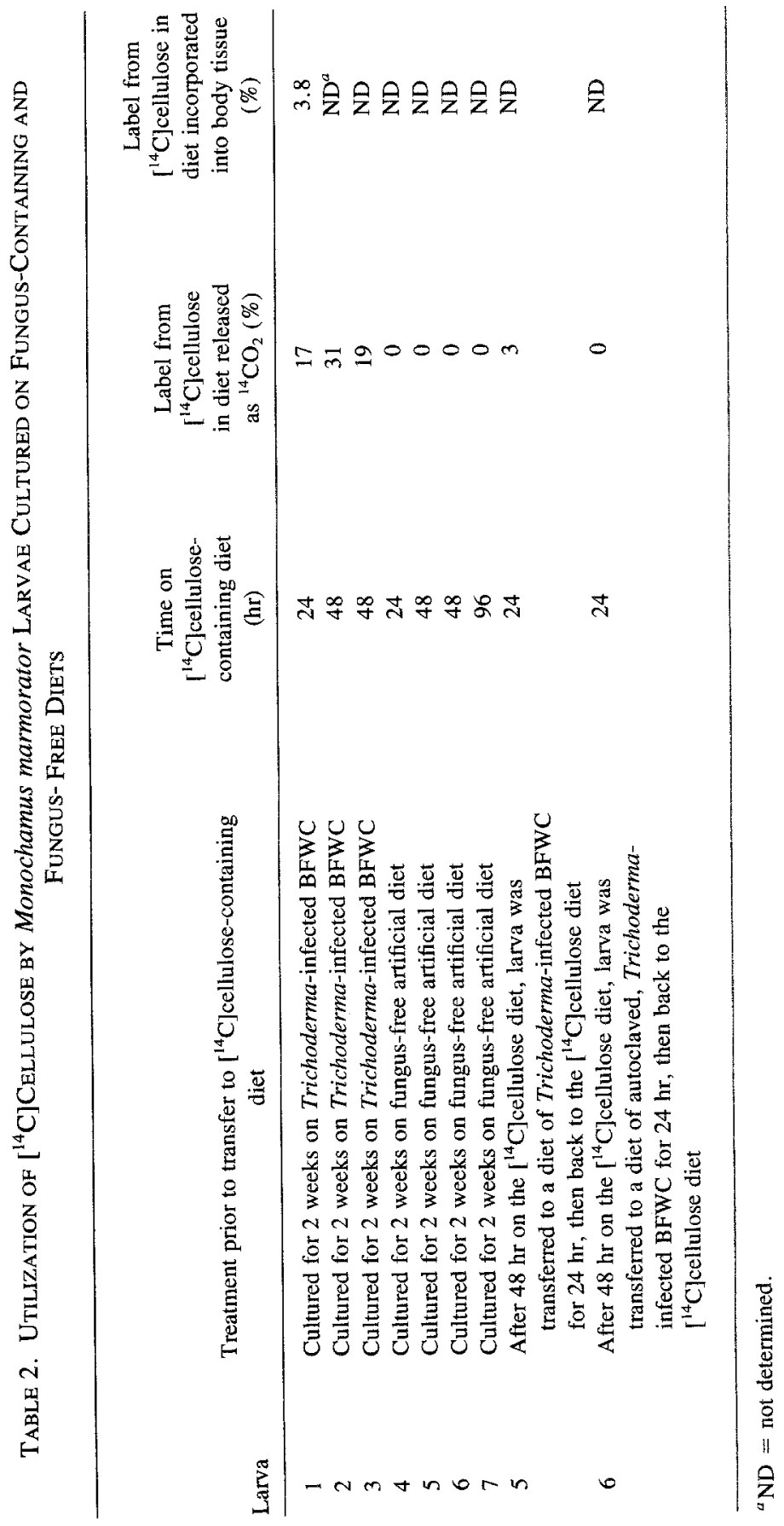


Table 3. Approximate Digestibility of Autoclaved, Fungus-Infected Balsam FIR WOOd ChIPS (BFWC) AND CELlulose IN BFWC BY Monochamus marmorator LARVAE

\begin{tabular}{|c|c|c|}
\hline \multirow[b]{2}{*}{$\begin{array}{l}\text { Larval diet immediately prior } \\
\text { to experiment }\end{array}$} & \multicolumn{2}{|c|}{ Approximate digestibility $(\%)^{a}$} \\
\hline & BFWC & $\begin{array}{l}\text { Cellulose in } \\
\text { BFWC }\end{array}$ \\
\hline $\begin{array}{l}\text { Four weeks on BFWC } \\
\text { permeated by live mycelium } \\
\text { of Trichoderma harzianum }\end{array}$ & $\begin{array}{l}52.2 \pm 1.9 \\
(4)\end{array}$ & $\begin{array}{c}26.7 \pm 4.0 \\
(4)\end{array}$ \\
\hline $\begin{array}{l}\text { Two weeks on artificial diet } \\
\text { followed by } 2 \text { weeks on } \\
\text { autoclaved, Trichoderma- } \\
\text { infected BFWC }\end{array}$ & $\begin{array}{l}20.8 \pm 5.4 \\
(3)\end{array}$ & $\begin{array}{l}3.7 \pm 2.6 \\
\quad(2)\end{array}$ \\
\hline
\end{tabular}

${ }^{a}$ Each value is the mean \pm standard error of the mean for the number of replicates given in parenthesis. Duration of experiment was one week.

the substrate. These experiments confirm that larvae can digest cellulose only after they have fed on a substrate that contains active fungal enzymes.

Assimilation Efficiencies. When reared on fungus-infected wood, $M$. marmorator larvae assimilated over $50 \%$ of the dry matter and $25 \%$ of the cellulose in their food (Table 3). By contrast, larvae reared on a fungus-free artificial diet assimilated only $21 \%$ of the dry matter of balsam fir wood chips and a negligible portion of the cellulose in balsam fir wood (Table 3). These results clearly demonstrate that acquired fungal cellulases make a significant quantitative contribution to the ability of $M$. marmorator larvae to utilize their natural food.

\section{DISCUSSION}

In this study we have demonstrated that the ability of the larvae of $M$. marmorator to digest cellulose is due to fungal enzymes ingested by the larvae during the consumption of fungus-infected wood. The larvae do not secrete the full complement of enzymes required for cellulose digestion, and in the absence of a dietary source of fungal cellulases, they are unable to digest cellulose. The demonstration that the capacity for cellulose digestion by the larvae of this cerambycid beetle is due to the acquisition of fungal enzymes calls into question the often-stated but untested hypothesis that other xylophagous cerambycid larvae, as well as anobiid and buprestid larvae, secrete all of their own cellulases. While there is convincing evidence that many of these beetles do produce endoglucanases active against carboxymethylcellulose (Martin, 1983), there is no compelling evidence that any species secretes the entire cellulase complex, and 
no evidence that rules out the possibility that cellulose digestion is mediated by ingested fungal enzymes.

The dependence upon ingested fungal enzymes to digest refractile polysaccharides has been demonstrated previously in the macrotermitine termites (Martin and Martin, 1978, 1979) and siricid woodwasps (Kukor and Martin, 1983). However, unlike the fungus-growing termites and siricid woodwasps, both of which have highly coevolved mutualistic associations with specific fungal symbionts, the cerambycid beetles are not known to maintain specific associations with particular species or strains of fungi, although cellulolytic fungi have been reported as surface contaminants on the eggs of $M$. scutellatus (Leach et al., 1937). Species of the genus Monochamus generally oviposit under the bark of sound timber, and the early larval instars feed in sound phloem and sapwood. It is only the later instars that expand their digestive capabilities by ingesting the enzymes of wood-rotting fungi that subsequently colonize the substrate. Finding that ingested enzymes derived from casual fungal associates play a vital role in the digestive processes of this wood-feeding beetle underscores the potential generality of a strategy for resource exploitation based upon the ingestion of microbial enzymes.

Fungal tissue plays an important role in the nutrition of a number of woodand detritus-feeding invertebrates. Because of the chemical alteration of substrate brought about by fungi and because of the ability of fungi to concentrate nutrients, fungus-infected wood is a resource of higher nutritive quality than uninfected wood. Numerous studies of xylophagous anobiid and cerambycid beetles have shown improved performance (decreased larval mortality, increased growth rate, increased pupal weight, increased adult body size, and increased fecundity) of animals reared on fungus-infected substrate compared to fungus-free substrate (Campbell and Bryant, 1940; Fisher, 1940, 1941; Campbell, 1941, Becker, 1942, 1968; Bletchly, 1953). It is reasonable that the exploitation of ingested fungal enzymes for the digestion of refractile polysaccharides would evolve in a species with a preference for fungus-infected wood and gut conditions compatible with enzyme function. We predict that additional examples of the acquisition of digestive enzymes will be provided by further studies of the nutritional ecology of xylophagous insects.

Acknowledgments - We thank the staff of the University of Michigan Biological Station and the Matthaei Botanical Gardens for use of their facilities. Dr. Barry OConnor, University of Michigan Museum of Zoology, provided access to the museum's cerambycid collection. R. VandeKopple, D. Mercer, and G. Keevil assisted in the field work; and N. Alpiner assisted in the cellulase purification. Dr. C.F. Yocum instructed us in the use of his FPLC system. Dr. D.T. Wicklow, USDA, ARS, Northern Regional Research Center, Peoria, Illinois, identified our isolate of $T$. harzianum. This research was supported by NSF grant PCM-82-03537 to M.M. Martin. 


\section{REFERENCES}

BECKER, G. 1942. Untersuchungen über die Ernahrungsphysiologie der Hausbockkäfer-larven. $Z$. Vergl. Physiol. 29:315-388.

BECKER, G. 1968. Einflusz von Ascomyceten und Fungi Imperfecti auf Larven von Hylotrupes bajulus (L.). Mater. Organ. 3:229-240.

Bernfeld, P. 1955. Amylases, $\alpha$ and $\beta$, pp. 149-150, in S.P. Colowick and N.O. Kaplan (eds.). Methods in Enzymology, Vol. 1. Academic Press, New York.

BLETCHLY, J.D. 1953. The influence of decay in timber on susceptibility to attack by the common furniture beetle, Anobium punctatum DeG. Ann. Appl. Biol. 40:218-221.

BRADFORD, M.M. 1976. A rapid and sensitive method for the quantitation of microgram quantities of protein utilizing the principle of protein-dye binding. Anal. Biochem. 72:248-254.

BUCHNER, P. 1928. Holznahrung und Symbiose. Springer Verlag, Berlin.

CAmpBelL, W.G. 1929. The chemical aspect of the destruction of oakwood by powder-post and death-watch beetles: Lyctus species and Xestobium species. Biochem. J. 23:1290-1293.

CAMPBELL, W.G. 1941. The relationship between nitrogen metabolism and the duration of the larval stage of the death-watch beetle (Xestobium rufovillosum DeG.) reared in wood decayed by fungi. Biochem. J. 35:1200-1208.

CampBell, W.G., and Bryant, S.A. 1940. A chemical study of the bearing of decay by Phellinus cryptarum Karst. and other fungi on the destruction of wood by the death-watch beetle (Xestobium rufovillosum DeG.). Biochem. J. 34:1404-14I4.

Chararas, C. 1981. Étude du comportement nutritionnel et de la digestion chez certains Cerambycidae xylophages. Mater. Org. 16:207-264.

Chararas, C., Courtors, J.E., Le Fay, A., and Thuillier, A. 1971. Biologie, évolution et nutrition de Phoracantha semipunctata, Coléoptère Cerambycidae spécifique des Eucalyptus. C.R. Soc. Biol. 165:1565-1568.

CôtÉ, W.A. 1977. Wood ultrastructure in relation to chemical composition. Recent Adv. Phytochem. 11:45-78.

Dasoz, R. 1968. La digestion du bois par les insectes xylophages. Ann. Biol. 7:1-38.

FISHER, R.C. 1940. Studies of the biology of the death-watch beetle, Xestobium rufovillosum DeG. Ann. Appl. Biol. 27:545-557.

FISHER, R.C. 1941. Studies of the biology of the death-watch beetle, Xestobium rufovillosum DeG. Ann. Appl. Biol. 28:244-260.

KuKor, J.J., and Martin, M.M. 1983. Acquisition of digestive enzymes by siricid woodwasps from their fungal symbiont. Science 220:1161-1163.

LEACH, J.G., ORR, L.W., and Christensen, C. 1937. The interrelationships of bark beetles and blue-staining fungi in felled Norway pine timber. J. Agric. Res. 49:315-341.

Linsley, E.G. 1959. Ecology of Cerambycidae. Annu. Rev. Entomol. 4:99-138.

Mansour, K., and Mansour-BeK, J.J. 1934a. The digestion of wood by insects and the supposed role of microorganisms. Biol. Rev. 9:363-382.

Mansour, K., and Mansour-BeK, J.J. 1934b. On the digestion of wood by insects. J. Exp. Biol. $11: 243-256$.

Martin, M.M. 1983. Cellulose digestion in insects. Comp. Biochem. Physiol.' 75A:313-324.

MARTIN, M.M. 1984. The role of ingested enzymes in the digestive processes of insects, pp. 155172, in J.M. Anderson, A.D.M. Rayner, and D. Walton (eds.). Animal-Microbial Interactions. Cambridge University Press, Cambridge.

Martin, M.M., and Martin, J.S. 1978. Cellulose digestion in the midgut of the fungus-growing termite Macrotermes natalensis: The role of acquired digestive enzymes. Science 199:1453 1455. 
Martin, M.M., and MarTin, J.S. 1979. The distribution and origins of the cellulolytic enzymes of the higher termite, Macrotermes natalensis. Physiol. Zool. 52:11-21.

Martin, M.M., Martin, J.S., Kukor, J.J., and Merritt, R.W. 1980. The digestion of protein and carbohydrate by the stream detritivore, Tipula abdominalis (Diptera: Tipulidae). Oecologia 46:360-364.

PARKIN, E.A. 1940. The digestive enzymes of some wood-boring beetle larvae. J. Exp. Biol. 17:364-377.

Piccioni, R., Bellemare, G., and Chua, N.-H. 1982. Methods of polyacrylamide gel electrophoresis in the analysis and preparation of plant polypeptides, pp. 985-1014, in M. Edelman, R.B. Hallick, and N.-H. Chua (eds.). Methods in Chloroplast Molecular Biology. Elsevier, Amsterdam.

Rapson, W.H. 1963. Cellulose from bleached wood pulp, pp. 22-24, in R.L. Whistler (ed.). Methods in Carbohydrate Chemistry, Vol. 3. Academic Press, New York.

UPDEGRAFF, D.M. 1969. Semimicro determination of cellulose in biological materials. Anal. Biochem. 32:420-424.

Uvarov, B.P. 1929. Insect nutrition and metabolism. Trans. Entomol. Soc. London 76:255-343. 